\title{
Potassium Fertilization Reduces the Severity of Asian Soybean Rust Under High Disease Pressure
}

\author{
Laércio Zambolim ${ }^{1}$, Ana Claudia R. Mochko ${ }^{1}$, Douglas Ferreira Parreira ${ }^{1} \&$ Samuel Vasconcelos Valadares ${ }^{2}$ \\ ${ }^{1}$ Departamento de Fitopatologia, Universidade Federal de Viçosa, Viçosa, Minas Gerais, Brazil \\ ${ }^{2}$ Departamento de Solos, Universidade Federal de Viçosa, Viçosa, Minas Gerais, Brazil \\ Correspondence: Laércio Zambolim, Departamento de Fitopatologia, Universidade Federal de Viçosa, 36570900, \\ Viçosa, Minas Gerais, Brazil. E-mail: zambolim@ufv.br
}

Received: March 30, 2019 Accepted: May 2, $2019 \quad$ Online Published: July 31, 2019

doi:10.5539/jas.v11n11p116 URL: https://doi.org/10.5539/jas.v11n11p116

The research is financed by Conselho Nacional de Pesquisas (CNPq); Fundação de Amparo a Pesquisa do Estado de Minas Gerais (FAPEMIG) and Coordenação de Pessoal de Nivel Superior (CAPES).

\begin{abstract}
Potassium $(\mathrm{K})$ is one of the essential nutrients for plants and is involved in many cellular processes which might influence the severity of diseases. There are few reports of the effect of increasing concentrations of $\mathrm{K}$ in the field on the severity of the Asian soybean rust (ASR) caused by Phakopsora pachyrhizi. In this context, the objective of this work was to verify the influence of increasing concentrations of K on ASR, in the absence and presence of chemical control, in conditions that highly favored the development of the disease. Two experiments were conducted under field conditions and two also in the field but in pots with a capacity of $100 \mathrm{~L}$. Evaluated concentrations of $\mathrm{K}$ were $0.0,100,200$, and $400 \mathrm{mg} / \mathrm{dm}^{3}$, respectively in a randomized complete block design. The application of the fungicide mixture azoxystrobin $(200 \mathrm{~g} / \mathrm{L})+$ cyproconazol $(80 \mathrm{~g} / \mathrm{L})$ was performed at 45 , 60 , and 75 days after emergence. The severity of the disease, area under the disease progress curve (AUDPC), rate of disease progression $(r)$, soybean productivity, and contents of chlorophyll $a, b$ and total were evaluated. The severity, AUDPC, and $r$ decreased with the increase of the concentration of $\mathrm{K}$ and fungicide application, while the rate of disease control and soybean productivity increased. Contents of chlorophyll $a, b$ and total also had higher values according to the increase in the concentration of $\mathrm{K}$. Potassium fertilization reduced the severity of ASR and grain yield under high disease pressure with or without chemical control.
\end{abstract}

Keywords: Phakopsora pachyrhizi, Glycine max, potassium fertilization, cultural control, Chlorophyll

\section{Introduction}

Brazil is a prominent producer and exporter of soybeans (Glycine max L. Merrill) worldwide. According to the estimates for 2016/2017 (CONAB, 2017), more than 113 million tons were harvested, $10.1 \%$ more than 2015/2016. The areas harvested in 2016/2017 also increased by approximately $1.9 \%$ in comparison to the last harvest (2015/2016), according to the survey carried out by CONAB (2017). Among the diseases attacking soybean crops, the Asian soybean rust (ASR) caused by the fungus Phakopsora pachyrizi, Sydow \& Sydow is the most severe and can generate losses of up to $100 \%$ (P. J. M. Andrade \& D. F de A. A. Andrade, 2002). Despite being easily confused with other diseases, its symptoms are very characteristic, including grayish-green to reddish brown lesions with pustules, mainly in the abaxial face of the leaves, sporadically with uredinia in the adaxial face of the leaves (Yorinori et al., 2004). Due to the lack of commercial cultivars of soybean with vertical resistance to this disease, its control is carried out with fungicides of the group of triazoles and strobilurins, alone or in a mixture. Due to the reduction of fungus sensitivity to these fungicides, a triple combination (triazol, a strobilurin, and carboxamide) has been used to control the disease. However, because $P$. pachyrhizi has already shown sensitivity to the fungicides of the triazole, strobilurin, and more recently carboxamide groups, it is important to adopt measures such as planting early varieties, eliminating alternative hosts, adequate plant density, fallowing, and balanced fertilization (Zambolim, 2006).

Despite the great importance of mineral fertilization, it is necessary to have a thorough knowledge of the role of these nutrients in plants, as they substantially influence resistance or susceptibility to pathogens (Zambolim et 
al., 2012; Marschner, 1995), and may favor the pathogen if deficient or in excess (Perrenoud, 1990). Among the nutrients required by plants, potassium $(\mathrm{K})$ stands out because it is essential for the maintenance of the water content in the cells by keeping them turgid, as well as by activating enzymes that are fundamental for metabolic reactions, including protein and sugar production, nitrogen $(\mathrm{N})$ uptake, and functional regulation of stomata (Fernandes, 2006). When $\mathrm{K}$ is deficient, the cell walls become thin, the stem becomes weakened, the roots become smaller, shorter, sugar and $\mathrm{N}$ accumulate in the leaves; therefore the plants become more susceptible to diseases (Bhaskarachary, 2011). Several authors have studied the use of $\mathrm{K}$ in the disease control of different plant species. Mascarenhas et al. (1995) observed a reduction in the incidence of Phomopsis phaseoli var. sojae in soybean seeds when level of potassium is adequate. In the onion, the increase in the concentration of $\mathrm{K}$ reduced mildew severity caused by Peronospora destructor (Devalash \& Sugha, 1997). In addition to the benefits of soil $\mathrm{K}$ fertilizer, its application on the leaf, associated or not with fungicide, resulted in a slight reduction of the ASR severity in the middle third of the plants at the stage R5.4 (Oliveira, 2007).

In some cases, as in millet, $\mathrm{K}$ fertilizer did not affect the pathogen Peronosclerospora sorghi causing mildew (Desmukuh et al., 1978). In soybeans, K fertilizer also did not have a significant impact on the aerial part of soybeans plants caused by Rhizoctonia solani under greenhouse conditions (Basseto et al., 2007). In most of the examples reported Chase (1989); Huber and Arny (1985); Ito et al. (1993); Marschner (1995); Pacumbaba et al. (1997); Sij et al. (1985) different sources and concentrations of K reduced disease severity, highlighting the importance of proper management of this nutrient in agriculture. The hypothese of this work is: does $\mathrm{K}$ fertilization reduces the severity of Asian soybean rust under high disease pressure with or without chemical control? Given this scenario and the scarcity of studies on the use of K to control ASR, this study aimed to evaluate different doses of this nutrient under high inoculum pressure, in the absence and presence of chemical control, in soybean plants.

\section{Material and Methods}

\subsection{General Procedures}

Four experiments were conducted at the Federal University of Viçosa (UFV), municipality of Viçosa, Minas Gerais, Brazil $\left(20^{\circ} 45^{\prime} 14^{\prime \prime} \mathrm{S}\right.$ and $\left.42^{\circ} 52^{\prime} 53^{\prime \prime} \mathrm{W}\right)$. The experiments were conducted to study the effect of the K fertilizer with or without azoxystrobin $(200 \mathrm{mg} / \mathrm{L})+$ cyproconazol $(80 \mathrm{~mL} / \mathrm{L})$ chemicals in the control of ASR. The tests were carried two in the field $\left(\mathrm{Fex}_{1}\right.$ and $\left.\mathrm{Fex}_{2}\right)$ and two in pots $\left(\mathrm{Pex}_{1}\right.$ and $\left.\mathrm{Pex}_{2}\right)$ with a capacity of $100 \mathrm{~L}$, measuring $55 \mathrm{~cm}$ in diameter and $80 \mathrm{~cm}$ in height, filled with soil poor in nutrients. Before the preparation of the experimental area and the installation of experiments, the soils from $\mathrm{Fex}_{1}, \mathrm{Fex}_{2}, \mathrm{Pex}_{1}$, and $\mathrm{Pex}_{2}$ were subjected to chemical analysis at the 0-20 cm layer (Table 1). Application of dolomitic limestone with relative power of total neutralization $(\mathrm{PRNT})=96 \%$ ) was made in both Fex and Pex soils to increase soil saturation to $70 \%$ in 20 days before planting. The soybean variety used was the transgenic "TMG 135". Fex and Pex were implemented in 2016 and 2017, respectively.

Table 1. Soil chemical analyses used in the field and pot experiments

\begin{tabular}{|c|c|c|c|c|c|c|c|}
\hline & $\mathrm{pH}-\mathrm{H}_{2} \mathrm{O}(1: 2.5)$ & ${ }^{4} \mathrm{P}$ & $\mathrm{K}$ & & $\mathrm{Ca}$ & $\mathrm{Mg}$ & $\mathrm{H}+\mathrm{Al}$ \\
\hline & & \multicolumn{3}{|c|}{-------- $\mathrm{mg} \mathrm{dm}^{-3}$------- } & \multicolumn{3}{|c|}{--------------- $\mathrm{cmol}_{\mathrm{c}} \mathrm{dm}^{-3}$-------------- } \\
\hline${ }^{1} \mathrm{Fex}_{1}$ and ${ }^{2} \mathrm{Fex}_{2}$ & 6.0 & 45.2 & 63 & & 3.1 & 1.1 & 1.5 \\
\hline${ }^{3} \mathrm{Pex}_{1}$ and $\mathrm{Pex}_{2}$ & 5.5 & 33.0 & 34 & & 2.0 & 1.0 & 1.0 \\
\hline Experiments & ECEC & CEC & \multicolumn{3}{|c|}{ Base saturation } & \multicolumn{2}{|c|}{ Remaining phosphorus } \\
\hline & $\mathrm{cmol} \mathrm{dm}^{-3}$ & $\mathrm{pH} 7.0$ & \multicolumn{3}{|c|}{$\%$} & \multicolumn{2}{|c|}{$\mathrm{mg} / \mathrm{L}$} \\
\hline${ }^{1} \mathrm{Fex}_{1}$ and ${ }^{2} \mathrm{Fex}_{2}$ & 2.8 & 5.6 & \multicolumn{3}{|c|}{62} & \multicolumn{2}{|c|}{21.5} \\
\hline${ }^{3} \mathrm{Pex}_{1}$ and $\mathrm{Pex}_{2}$ & 1.5 & 4.5 & \multicolumn{3}{|c|}{46} & \multicolumn{2}{|l|}{15.3} \\
\hline
\end{tabular}

Note. ${ }^{1}$ Field experiment $1 ;{ }^{2}$ Field experiment ${ }_{2} ;{ }^{3}$ Pot experiment ${ }_{1}$ and Pot experiment ${ }_{2} ;{ }^{4} \mathrm{P}$ : phosphorus; K: potassium; Ca: calcium; Mg: magnesium; $\mathrm{H}+\mathrm{Al}$ : hydrogen + aluminum; ECEC: effective cation exchange capacity; CEC: cation exchange capacity.

By the time of soybean sowing, the fertilization with phosphate, $\mathrm{K}$, and $\mathrm{N}$ was made in furrows, using triple superphosphate $\left(42 \% \mathrm{P}_{2} \mathrm{O}_{5}\right)$, potassium chloride $\left(60 \% \mathrm{~K}_{2} \mathrm{O}\right)$, and urea $(44 \% \mathrm{~N})$. Applications of potassium chloride and urea were performed three times, with the first application in planting, the second before flowering, and the last during flowering. 


\subsection{Production of Uredospores}

The uredospores produced for inoculation were multiplied in a soybean susceptible variety (transgenic "TMG 135 ") in a greenhouse, using an isolate of $P$. pachyrhizi of the Plant Protection Laboratory, UFV. The suspension of uredospores was made in water and Tween $80(0.1 \mu \mathrm{g} / \mathrm{mL})$ at $1 \times 10^{5} / \mathrm{mL}$ with germination rate higher than $90 \%$, produced in a greenhouse.

\subsection{Inoculation Procedure}

The inoculations were done with uredospore suspension of $P$. pachyrhizi at the vegetative stage, 15 days before the application of fungicides, to guarantee favorable conditions for the disease. They were carried out in plants of the two border rows of $\mathrm{Fex}_{1}$ and $\mathrm{Fex}_{2}$, and all of the ten potted plants of $\mathrm{Pex}_{1}$ and $\mathrm{Pex}_{2}$. The inoculation was made with a backhand sprayer with a fan-tip nozzle, using $200 \mathrm{~L} /$ ha of inoculum suspension.

\subsection{Treatments and Experimental Design}

The experiments $\mathrm{Fex}_{1}$ and $\mathrm{Fex}_{2}$ were established in a randomized complete block design with four replicates, in a $4 \times 2$ factorial, considering four doses of $\mathrm{K}\left(0.0,100,200,400 \mathrm{mg} / \mathrm{dm}^{3}\right)$, with or without fungicide Phosphorus and nitrogen doses were maintained fixed at $100 \mathrm{mg} / \mathrm{dm}^{3}$ and $150 \mathrm{mg} / \mathrm{dm}^{3}$, respectively. Each replicate consisted of rows measuring $6 \mathrm{~m}$ in length, with four rows of plants, spaced at $0.50 \mathrm{~m}$. Two side edges rows and two centers rows were considered for a total of 200,000 plants/ha.

$\mathrm{Pex}_{1}$ and $\mathrm{Pex}_{2}$ were established in randomized complete block design with three replicates of ten plants in each pot. The $4 \times 2$ split-plot design was adopted, using four concentrations of $K\left(0.0,100,200,400 \mathrm{mg} / \mathrm{dm}^{3}\right)$, with or without fungicide. In the treatments with chemical control, the fungicide azoxystrobin + cyproconazol (Priori XTRA ${ }^{\circledR}$ ) was applied at $300 \mathrm{~mL} / \mathrm{ha}$, on plants at the $\mathrm{R}_{1}$ stage (beginning of flowering) and afterward, the mixture was reapplied three times, once every 15 days. The application of the fungicide was made with a pressurized atomizer with $\mathrm{CO}_{2}$, at 80 psi of pressure, using a conical jet nozzle puffing $150 \mathrm{~L} / \mathrm{ha}$.

\subsection{Evaluation Procedure}

The evaluation of the severity of Asian soybean rust (ASR) in $\mathrm{Fex}_{1}, \mathrm{Fex}_{2}, \mathrm{Pex}_{1}$, and $\mathrm{Pex}_{2}$ was made by counting the number of lesions per $\mathrm{cm}^{2}$ on six leaflets of the middle third of the plant rows using a stereoscope microscope (80×), of plants at the stages $R_{1}, R_{3}$, and $R_{5}$ (flowering and pod filling stages). In $P_{e x}$ and $P_{2} x_{2}$, the evaluations were performed in plants at the stages $V_{8}$ (last stage of vegetative growth), $R_{1}, R_{3}$, and $R_{5}$. Six leaflets of the middle third of the plants of each pot were digitalized with a resolution of $600 \mathrm{dpi}$ and, from the scanned images of the abaxial face of leaves, the severity was determined using QUANT ${ }^{\circledR}$ (Vale et al., 2003). Based on the severity data from the different evaluations, the area under the disease progress curve (AUDPC) was calculated by the trapezoidal integration method (Kranz 1988). The rate of disease progression $(r)$ and the rate of control were calculated based on the difference between the control (with the application of fungicide) and treatments (without fungicide) at each dose evaluated.

\subsection{Chlorophyll Content}

The total chlorophyll content was obtained from five disks with $0.5 \mathrm{~cm}$ in diameter collected from different leaves of the middle third of soybeans at the $\mathrm{R}_{1}$ stage, using a hollowed steel punch. The disks were placed in test tubes wrapped in foil containing $5 \mathrm{~mL}$ of dimethylsulfoxide (DMSO) previously saturated with calcium carbonate $\left(\mathrm{CaCO}_{3}\right)$ and incubated at room temperature $\left(25^{\circ} \mathrm{C}\right)$ for 12 hours. To read the pigments, the BIO-RAD spectrophotometer SmartSpec 3000, was used at the wavelengths of $665 \mathrm{~nm}$ and $649 \mathrm{~nm}$. Values for each wavelength were used in the calculation of Wellburns (1994) equation.

\subsection{Productivity}

The soybean productivity from the experiments was obtained from the sampling of ten plants per row and ten plants per pot in each replicate. Afterward, the pods were harvested, and the grains were weighed using a electronic digital scale $\left(\right.$ Mettler $^{\mathrm{R}}$ ) The production data on ten plants were converted into $\mathrm{kg} / \mathrm{ha}$, considering a population of 200,000 plants/ha.

Data of soybean seeds weight were submitted to analysis of variance (ANOVA) in the Sisvar computer program, after evaluation of normality and homoscedasticity by the Shapiro-Wilk and Bartlett tests, respectively. The effects of the quantitative treatments were calculated through regression analysis. 


\section{Results}

\subsection{Analysis of Variance}

For all treatments of the experiments $\mathrm{Fex}_{1}, \mathrm{Fex}_{2}, \mathrm{Pex}_{1}$, and $\mathrm{Pex}_{2}$, there was no significant difference $(\mathrm{p}<0.05)$ in the interaction between the concentration of potassium treatments with or without fungicide. Moreover, no significant differences were obtained between the concentrations of $\mathrm{K}$ added to the soil, for all the variables evaluated (Table 2). Thus, the unfolding was performed by regression of quantitative variables to obtain a more representative model.

Table 2. Analysis of variance of the effects of potassium (K) fertilization on severity (sev), Area Under the Disease Progression Curve (AUDPC), production (pro), chlorophyll $a$ (chl $a$ ), chlorophyll $b$ (chl $b$ ) and total chlorophyll $(\mathrm{chl} t)$ of the field experiment $1\left(\mathrm{Fex}_{1}\right)$, field experiment $2\left(\mathrm{Fex}_{2}\right)$, pot experiment ${ }_{1}\left(\mathrm{Pex}_{1}\right)$ and pot experiment 2 $\left(\mathrm{Pex}_{2}\right)$, sprayed (S) with the fungicide azoxystrobin + cyproconazol

\begin{tabular}{|c|c|c|c|c|}
\hline Assay & Variables & $\mathbf{S}$ & $\mathbf{K}$ & $\mathbf{S} \times \mathbf{K}$ \\
\hline \multirow[t]{3}{*}{$\mathrm{Fex}_{1}$} & $\mathrm{Sev}$ & $* * *$ & $* * *$ & $\mathrm{Ns}$ \\
\hline & AUDPC & $* * *$ & $* * *$ & Ns \\
\hline & Pro & $* * *$ & $* * *$ & Ns \\
\hline \multirow[t]{3}{*}{$\mathrm{Fex}_{2}$} & $\mathrm{Sev}$ & $* * *$ & $* *$ & Ns \\
\hline & AUDPC & $* * *$ & $* *$ & Ns \\
\hline & Pro & $* * *$ & $* *$ & Ns \\
\hline \multirow[t]{6}{*}{$\mathrm{Pex}_{1}$} & $\mathrm{Sev}$ & $* * *$ & $* * *$ & Ns \\
\hline & AUDPC & $* * *$ & $* * *$ & Ns \\
\hline & Pro & $* * *$ & $* * *$ & Ns \\
\hline & Chl $a$ & $* * *$ & $* * *$ & Ns \\
\hline & Chl $b$ & $* * *$ & $* * *$ & Ns \\
\hline & Chl t & $* * *$ & $* * *$ & Ns \\
\hline \multirow[t]{6}{*}{$\mathrm{Pex}_{2}$} & $\mathrm{Sev}$ & $* * *$ & $* * *$ & Ns \\
\hline & AUDPC & $* * *$ & $* * *$ & Ns \\
\hline & Pro & $* * *$ & $* * *$ & $* *$ \\
\hline & Chl $a$ & $* * *$ & $* * *$ & Ns \\
\hline & Chl b & $* * *$ & $* * *$ & Ns \\
\hline & Chl t & $* * *$ & $* * *$ & Ns \\
\hline
\end{tabular}

Note. The results are not significant (ns), significant to $\mathrm{P} \leq 0.05\left(^{*}\right)$, significant to $\mathrm{P} \leq 0.01\left(^{* *}\right)$ or $\mathrm{P} \leq 0.001$ $(* * *)$.

\subsection{Severity and Area Under Disease Progress Curve (AUDPC)}

Table 3 shows the results of the $\mathrm{n}^{\circ}$ lesions $/ \mathrm{cm}^{2}$ and AUDPC of ASR in $\mathrm{Fex}_{1}, \mathrm{Fex}_{2}, \mathrm{Pex}_{1}$, and $\mathrm{Pex}_{2}$, with or without azoxystrobin + cyproconazol, submitted to different concentrations of $\mathrm{K}$. The average of the severity of the treatments in the presence and absence of chemical control at the doses of 0 to $400 \mathrm{mg} / \mathrm{dm}^{3}$ of Fex 1 and Fex , were 24.4, 19.6, 1056.6 and 782.4, respectively. The joint mean of the AUDPC of $\mathrm{Pex}_{1}$ and $\mathrm{Pex}_{2}$, with or without chemical control, was 779.0 and 768.6, respectively, considering the concentrations of $\mathrm{K}$ from 0 to $400 \mathrm{mg} / \mathrm{dm}^{3}$ added to the soil (Table 3 ).

The severity data corresponding to concentrations of $\mathrm{K}$ from 100 to $400 \mathrm{mg} / \mathrm{dm}^{3}$ are equal to each other and different significantlyed from the dose 0 (zero), for both lesions $/ \mathrm{cm}^{2}$ and AUDPC. The lowest values of severity and AUDPC for $\mathrm{Fex}_{1}, \mathrm{Fex}_{2}, \mathrm{Pex}_{1}$, and $\mathrm{Pex}_{2}$ corresponded to $\mathrm{K}$ at $200 \mathrm{mg} / \mathrm{dm}^{3}$; however, this dose did not differ significantly from the other concentrations of $\mathrm{K}$ added to the soil (Table 3 ). 
Table 3. Severity of Asian soybean rust and Area Under Disease Progress Curve (AUDPC) on $\mathrm{Fex}_{1}, \mathrm{Fex}_{2}, \mathrm{Pex}_{1}$ and $\mathrm{Pex}_{2}$ sprayed and not sprayed with azoxystrobin + cyproconazol submited to different doses of potassium $(\mathrm{K})$

\begin{tabular}{|c|c|c|c|c|c|c|}
\hline \multirow{2}{*}{$\mathrm{K}\left(\mathrm{mg} / \mathrm{dm}^{3}\right)$} & \multicolumn{2}{|c|}{ Severity (lesions $/ \mathrm{cm}^{2}$ ) } & \multicolumn{4}{|c|}{ AUDPC } \\
\hline & $\mathrm{Fex}_{1}{ }^{1}$ & $\mathrm{Fex}_{2}{ }^{1}$ & $\mathrm{Fex}_{1}$ & $\mathrm{Fex}_{2}$ & $\mathrm{Pex}_{1}^{2}$ & $\mathrm{Pex}_{2}^{2}$ \\
\hline 0 & $33.2 \mathrm{aA}^{1}$ & $22.8 \mathrm{bA}$ & $1380.7 \mathrm{aA}$ & $914.7 \mathrm{bA}$ & $1013.0 \mathrm{aA}$ & $866.4 \mathrm{bA}$ \\
\hline 100 & $22.6 \mathrm{bB}$ & $18.3 \mathrm{bB}$ & $942.9 \mathrm{bB}$ & $726.6 \mathrm{bB}$ & $723.3 \mathrm{aB}$ & $784.0 \mathrm{Ab}$ \\
\hline 200 & $20.3 \mathrm{bB}$ & $18.2 \mathrm{bB}$ & $910.0 \mathrm{bB}$ & $701.2 \mathrm{bB}$ & $676.9 \mathrm{aB}$ & $690.2 \mathrm{aB}$ \\
\hline 400 & $21.5 \mathrm{bB}$ & $19.3 \mathrm{bB}$ & $992.9 \mathrm{bB}$ & $787.2 \mathrm{bB}$ & $702.8 \mathrm{aB}$ & $733.8 \mathrm{aB}$ \\
\hline Average & 24.4 & 19.6 & 1056.6 & 782.4 & 779.0 & 768.6 \\
\hline CV (\%) & 16.9 & 15.1 & 17.6 & 14.2 & 16.2 & 13.9 \\
\hline
\end{tabular}

Note. ${ }^{1}$ Field experiment 1 and $2 ;{ }^{2}$ Pot experiment 1 and 2.

${ }^{2}$ Data followed by the same capital letter in the column and small letter on the line in each experiment do not differ significantly by the Tukey test $(\mathrm{P}<0.05)$.

The effect of concentrations of K on ASR severity, after 75 days that the soybeans emerged, in the Fex ${ }_{1}$, Fex 2 , $\mathrm{Pex}_{1}$, and $\mathrm{Pex}_{2}$ are depicted in Figures 1 and 2, respectively. In Figure 1, each curve represents the mean values of the treatments with and without azoxystrobin + cyproconazol.

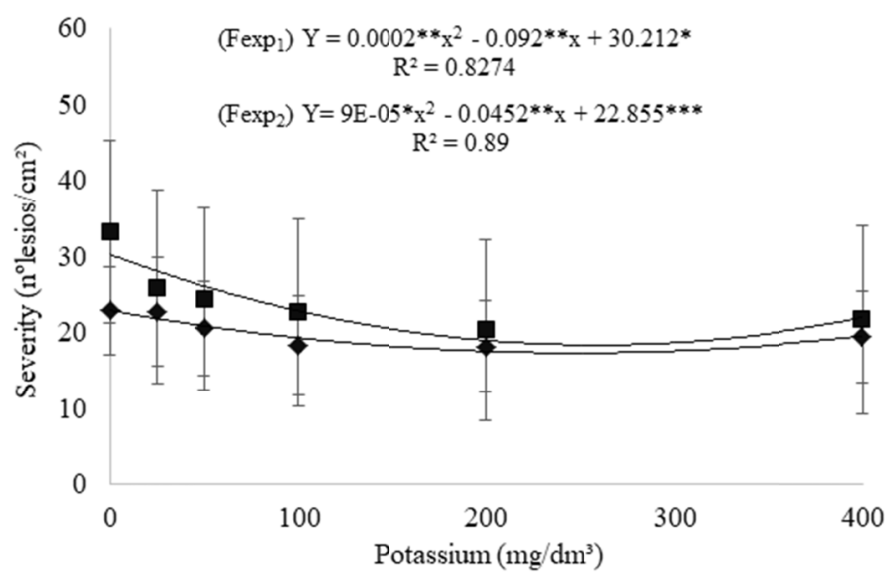

Figure 1. Effect of potassium doses, on Asian soybean rust severity, 75 days after plant emergence, on field experiment $1\left(\mathrm{Fex}_{1}\right)$ and field experiment $2\left(\mathrm{Fex}_{2}\right)$. Each line represent average of the treatment sprayed and not sprayed with azoxystrobin + cyproconazol

Note. $* * *$ Significant $0.001 \% ; * *$ Significant $1 \%$ and $*$ Significant $5 \%$.

In Figure 2, the regression line represents the mean values of treatments in $\mathrm{Pex}_{1}$ and $\mathrm{Pex}_{2}$ with and without the fungicide. 


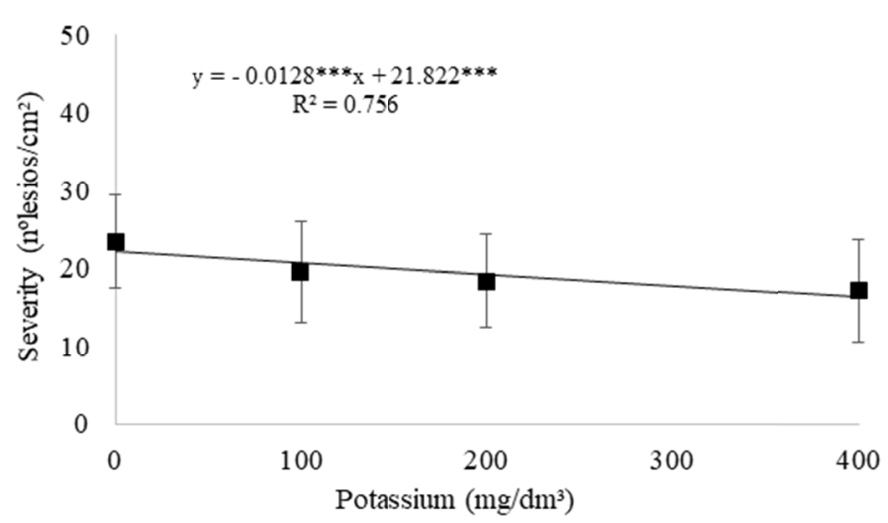

Figure 2. Average of pot experiments of the effect of potassium doses on Asian soybean rust severity 75 days after plant emergence. The line represent the average of the $\mathrm{Pex}_{1}$ and $\mathrm{Pex}_{2}$ treatments sprayed and not sprayed with azoxystrobin + cyproconazol

Note. ${ }^{* * *}$ Significant $0.001 \%$.

Potassium fertilizer reduced ASR severity up to the dose of $200 \mathrm{mg} / \mathrm{dm}^{3}$ in $\mathrm{Fex}_{1}$ and $\mathrm{Fex}_{2}$. The quadratic model was the best fit for the severity data, assessed at 75 days after the emergence of plants (Figure 1). On the other hand, the severity in $\mathrm{Pex}_{1}$ and $\mathrm{Pex}_{2}$ was adjusted to the linear model, that is, as the concentration of $\mathrm{K}$ increased from 0 to $400 \mathrm{mg} / \mathrm{dm}^{3}$, the severity decreased (Figure 2).

Figure 3 illustrates the results of AUDPC of soybean plants submitted to different concentrations of K, with and without azoxystrobin + cyproconazol in $\mathrm{Fex}_{1}$ and $\mathrm{Fex}_{2}$. Each line represents the mean of the treatments with and without the fungicide. AUDPC decreased as the concentration of $\mathrm{K}$ in the soil increased up to $200 \mathrm{mg} / \mathrm{dm}^{3}$ in both $\mathrm{Fex}_{1}$ and $\mathrm{Fex}_{2}$. From that dose, a trend in the increase of the AUDPC was observed (Figure 3).

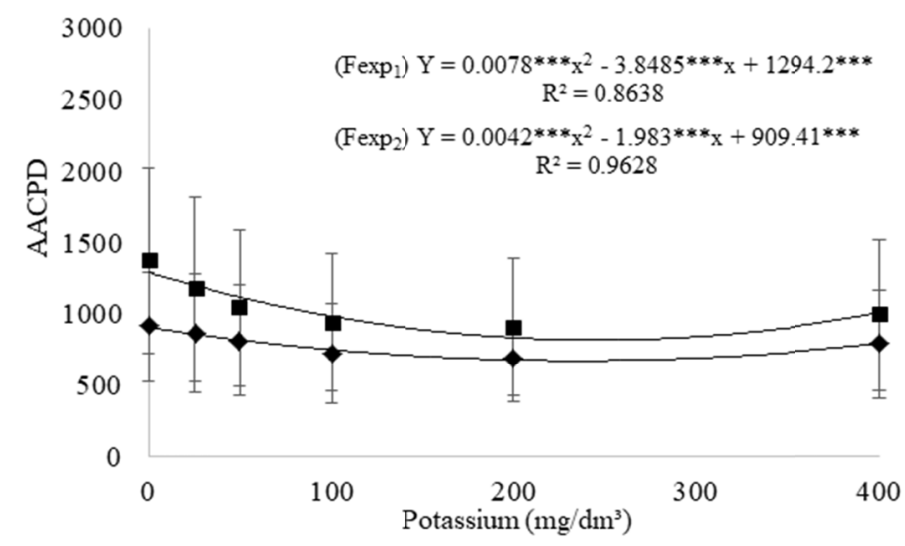

Figure 3. Area under disease progress curve (AUDPC) of soybean plants submitted to different doses of potassium, sprayed and not sprayed with azoxistrobina + cyproconazol) on field experiment $1\left(\mathrm{Fex}_{1}\right)$ and field experiment $2\left(\mathrm{Fex}_{2}\right)$. Each line represent the average of the treatments sprayed and not sprayed with azoxystrobin + cyproconazol in 2016

Note. ${ }^{* * *}$ Significant $0.001 \%$.

Figure 4 shows combined results from the AUDPC of soybean plants submitted to different concentrations of K, with and without application of azoxystrobin + cyproconazol in $\mathrm{Fex}_{1}$ and $\mathrm{Fex}_{2}$. The AUDPC of the treatments with fungicide was significantly lower than the treatments without, at all the doses evaluated. The quadratic model was the best fit to explain the reduction of AUDPC up to the dose of $200 \mathrm{mg} / \mathrm{dm}^{3}$ (inflection point), both in treatments with and without chemical control. 


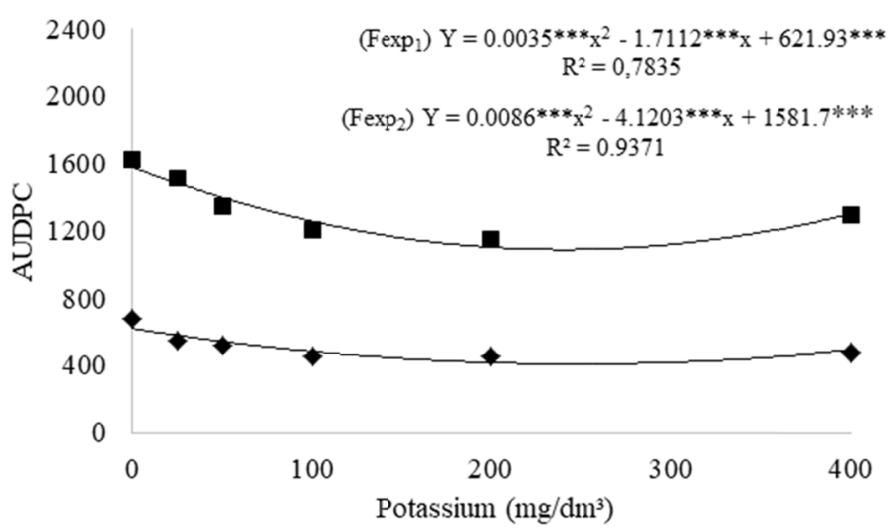

Figure 4. Area Under Disease Progress Curve (AUDPC) of soybean plants submitted to different doses of potassium sprayed and not sprayed with azoxystrobin + cyproconazol) on field experiment $1\left(\mathrm{Fex}_{1}\right)$ and Field experiment $2\left(\mathrm{Fex}_{2}\right)$. Each line represent the average of the treatment sprayed and not sprayed with azoxystrobin + cyproconazol in 2017

Note. $* * *$ Significant $0.001 \%$.

Figure 5 depicts the combined results of AUDPC of soybean plants submitted to different concentrations of K, with and without azoxystrobin + cyproconazol in $\mathrm{Pex}_{1}$. A linear model with the downstream line was best adjusted for the treatments with the fungicide, as the concentration of $\mathrm{K}$ was increasing from 0 to $400 \mathrm{mg} / \mathrm{dm}^{3}$. On the other hand, for the treatments without fungicide, the quadratic model was best adjusted. The inflection point was reached at $246 \mathrm{mg} / \mathrm{dm}^{3}$. After this value, the curve ascended to the concentration of K of $400 \mathrm{mg} / \mathrm{dm}^{3}$.

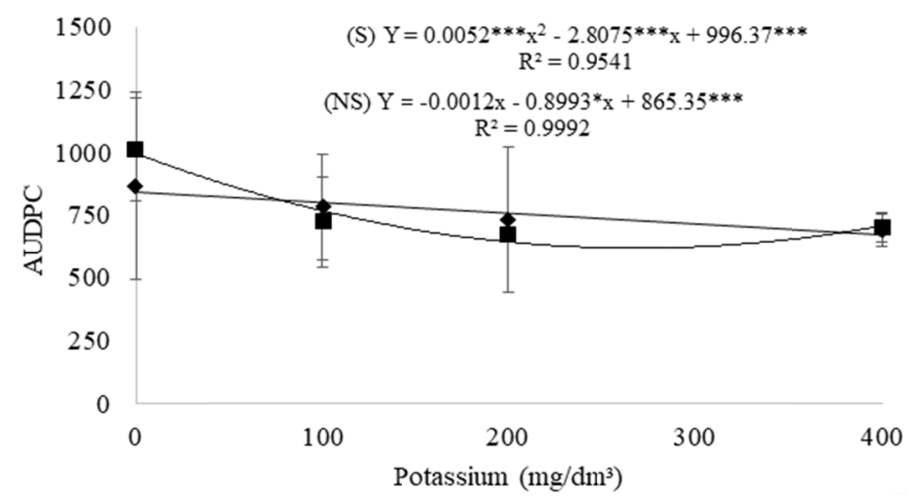

Figure 5. Area Under Disease Progress Curve (AUDPC) of soybean plants submitted to different doses of potassium sprayed (S) and not sprayed (NS) with azoxystrobin + cyproconazol) on pot experiment $1\left(\mathrm{Pex}_{1}\right)$.

Each line represent the average of the treatment sprayed and not sprayed with azoxystrobin + cyproconazol in 2017

Note. ${ }^{* * *}$ Significant $0.001 \%$; $*$ Significant $5 \%$.

\subsection{The Rate of Disease Progression ( $r$ )}

Table 4 shows the $r$ values according to the concentrations of $\mathrm{K}$ added to the soil. The chemical control and the increase of the $\mathrm{K}$ fertilizer concentration reduced the $r$ values in comparison to the treatments that were not submitted to the control of ASR. The lowest $r$ values for the treatments with fungicide (0.74) and without (1.53) in $\mathrm{Fex}_{1}$ and $\mathrm{Fex}_{2}$ were at $200 \mathrm{mg} / \mathrm{dm}^{3}$. For Pex ${ }_{1}$ and $\mathrm{Pex}_{2}$, the lowest $r$ values corresponded to $400 \mathrm{mg} / \mathrm{dm}^{3}(0.66)$ and (1.27), respectively (Table 4). 
Table 4. Average of $\mathrm{Fex}_{1}$ and $\mathrm{Fex}_{2}, \mathrm{Pex}_{1}$ and $\mathrm{Pex}_{2}$ of the disease infection rate (r) of Asian soybean rust on plants submited to different doses of potassium sprayed (S) and not sprayed (NS) with azoxystrobin + cyproconazol

\begin{tabular}{llllll}
\hline \multirow{2}{*}{$\mathrm{K}\left(\mathrm{mg} / \mathrm{dm}^{3}\right)$} & \multicolumn{2}{c}{${ }^{1} \mathrm{Fex}_{1}$ and ${ }^{2} \mathrm{Fex}_{2}$} & & \multicolumn{2}{c}{${ }^{3} \mathrm{Pex}_{1}$ and ${ }^{4} \mathrm{Pex}_{2}$} \\
\cline { 2 - 3 } \cline { 5 - 6 } & $\mathrm{S}$ & $\mathrm{NS}$ & & $\mathrm{S}$ & $\mathrm{NS}$ \\
\hline 0 & $1.12(0.18)^{5}$ & $2.10(0.25)$ & & $0.89(0.18)$ & $1.41(0.13)$ \\
200 & $0.75(0.15)$ & $1.67(0.17)$ & & $0.77(0.16)$ & $1.36(0.12)$ \\
400 & $0.74(0.14)$ & $1.53(0.13)$ & & $0.75(0.15)$ & $1.30(0.12)$ \\
Average & $0.76(0.15)$ & $1.66(0.16)$ & & $0.66(0.14)$ & $1.27(0.11)$ \\
\hline
\end{tabular}

Note. ${ }^{1} \mathrm{Fex}_{1}$-field experiment $1 ;{ }^{2} \mathrm{Fex}_{2}$-field experiment $2 ;{ }^{3} \mathrm{Pex}_{1}$-pot experiment $1 ;{ }^{4} \mathrm{Pex}_{2}$-pot experiment 2.

${ }^{5}$ Means standard deviation.

The Pearson correlation coefficient values for chlorophyll $a, b$, and total and severity is shown in Table 5. Pearson correlation coefficients were significant for severity in the $\mathrm{Pexp}_{2}$ in sprayed (S) and non sprayed (NS); chlorophyll $a$ in $\operatorname{Pexp}_{1}$ (S and NS) and $\mathrm{Pexp}_{2}$ (NS); chlorophyll $b$ in $\operatorname{Pexp}_{1}$ and $\mathrm{Pexp}_{2}(\mathrm{NS})$; total chlorophyll in Pexp $(\mathrm{NS})$. Therefore, the contents of chlorophyll $a, b$ and total correlated significantly with treatments with and without fungicides in at least one experiment.

Table 5. Person's simple correlation coefficients of the parameter productivity of soybeans of sprayed (S) and non-sprayed (NS) with fungicide azoxystrobin + cyproconazol in relation to the chlorophyll $a$ (Chl $a$ ), chlorophyll $b(\mathrm{Chl} b)$ and total chlorophyll $(\mathrm{Chl} t)$ contents and severity (Sev) of Asian soy rust in $\mathrm{Fex}_{1}, \mathrm{Fex}_{2}$, $\mathrm{Pex}_{1}$ and $\mathrm{Pexp}_{2}$

\begin{tabular}{|c|c|c|c|c|c|c|}
\hline & & & Chl $a$ & Chl $b$ & Chl $t$ & Sev \\
\hline \multirow{8}{*}{ 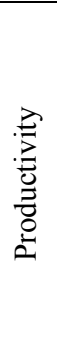 } & \multirow[t]{2}{*}{${ }^{1} \mathrm{Fex}_{1}$} & $\mathrm{~S}$ & - & - & - & $-0.81^{\mathrm{ns}}$ \\
\hline & & NS & - & - & - & $-0.76^{n s}$ \\
\hline & \multirow{2}{*}{${ }^{2} \mathrm{Fex}_{2}$} & S & - & - & - & $-0.74^{\mathrm{ns}}$ \\
\hline & & NS & - & - & - & $-0.57^{\mathrm{ns}}$ \\
\hline & \multirow[t]{2}{*}{${ }^{3} \mathrm{Pex}_{1}$} & $\mathrm{~S}$ & $0.93 *$ & $0.84^{\mathrm{ns}}$ & $0.86^{\mathrm{ns}}$ & $-0.89^{\mathrm{ns}}$ \\
\hline & & NS & $0.96^{*}$ & $0.96^{*}$ & $0.98^{*}$ & $-0.57^{\mathrm{ns}}$ \\
\hline & \multirow[t]{2}{*}{${ }^{4} \mathrm{Pex}_{2}$} & $\mathrm{~S}$ & $0.84^{\mathrm{ns}}$ & $0.84^{\mathrm{ns}}$ & $0.95^{\mathrm{ns}}$ & $-0.99 *$ \\
\hline & & NS & $1.00 *$ & $0.87^{*}$ & $0.79^{\mathrm{ns}}$ & $-0.97 *$ \\
\hline
\end{tabular}

Note. $*$ Significant at $5 \%$ probability of error, by $\mathrm{t}$ test $;{ }^{\mathrm{ns}}$ Not significant.

${ }^{1} \mathrm{Fex}_{1}$-field experiment $1 ;{ }^{2} \mathrm{Fex}_{2}$-field experiment $2 ;{ }^{3} \mathrm{Pex}_{1}$-pot experiment 1 and ${ }^{4} \mathrm{Pex}_{2}$-pot experiment 2.

\subsection{Productivity}

The soybean productivity values, according to concentrations of $\mathrm{K}$ administered and the application of fungicides, are in Table 6 . The mean productivity of the treatments with and without fungicide was $4706.0 \mathrm{k} / \mathrm{ha}$ and $3308.2 \mathrm{k} / \mathrm{ha} \mathrm{(Fex1)} \mathrm{and} 4303.1 \mathrm{k} / \mathrm{ha}$ and $2635.1 \mathrm{~kg} / \mathrm{ha}$ (Fex2), respectively. Considering the experiments in pots, the mean productivity with and without fungicide was $1927.6 \mathrm{~kg} / \mathrm{ha}$ and $1301.6 \mathrm{~kg} / \mathrm{ha}\left(\mathrm{Pex}_{1}\right) ;$ and 1908.5 $\mathrm{kg} / \mathrm{ha}$ and $1266.6 \mathrm{~kg} / \mathrm{ha}\left(\mathrm{Pex}_{2}\right)$, respectively. Therefore, the soybean productivity in the field experiments was superior to that of the pot experiments. Treatments with and without fungicide, at $100 \mathrm{mg} / \mathrm{dm}^{3}, 200 \mathrm{mg} / \mathrm{dm}^{3}$ and $400 \mathrm{mg} / \mathrm{dm}^{3}$ of $\mathrm{K}$, in the $\mathrm{Fex}_{1}$ and $\mathrm{Fex}_{2}$, differed significantly from the control (no K added). The difference was found between the concentrations of $\mathrm{K}$ of $100 \mathrm{mg} / \mathrm{dm}^{3}, 200 \mathrm{mg} / \mathrm{dm}^{3}$ and $400 \mathrm{mg} / \mathrm{dm}^{3}$ of the Fex ${ }_{1}$ and $F e x_{2}$. Considering Pex ${ }_{1}$ and $\mathrm{Pex}_{2}$, the concentrations of $\mathrm{K}$ of 0 and $100 \mathrm{mg} / \mathrm{dm}^{3}$ did not differ from the other treatments (200 and $400 \mathrm{mg} / \mathrm{dm}^{3}$ ); no significant difference was found between the last two doses. 
Table 6. Soybean productivity in sprayed (S) and not sprayed (NS) treatments with fungicide (azoxystrobin + cyproconazole $)$ in different potassium dose $(\mathrm{K})$ in two field $\left(\mathrm{Fex}_{1}\right)$ and $\left(\mathrm{Fex}_{2}\right)$ and two pot experiments $\left(\mathrm{Pex}_{1}\right)$ and $\left(\mathrm{Pex}_{2}\right)$

\begin{tabular}{|c|c|c|c|c|c|c|c|c|}
\hline \multirow{3}{*}{$\mathrm{K}\left(\mathrm{mg} / \mathrm{dm}^{3}\right)$} & \multicolumn{8}{|c|}{ Soybean productivity $(\mathrm{Kg} / \mathrm{ha})$} \\
\hline & \multicolumn{2}{|c|}{$\mathrm{Fex}_{1}$} & \multicolumn{2}{|c|}{$\mathrm{Fex}_{2}$} & \multicolumn{2}{|c|}{$\mathrm{Pex}_{1}$} & \multicolumn{2}{|c|}{$\mathrm{Pex}_{2}$} \\
\hline & $\mathrm{S}$ & NS & $\mathrm{S}$ & NS & $\mathrm{S}$ & NS & $\mathrm{S}$ & NS \\
\hline 0 & $4306.0 \mathrm{aA}^{*}$ & $1996.0 \mathrm{bA}$ & $3856.2 \mathrm{Aa}$ & $1821.0 \mathrm{aA}$ & $1228.0 \mathrm{aA}$ & $938.0 \mathrm{aA}$ & $1156.0 \mathrm{aA}$ & $845.4 \mathrm{aA}$ \\
\hline 100 & $4766.0 \mathrm{aAB}$ & $2640.3 \mathrm{bA}$ & $4347.1 \mathrm{aB}$ & $2316.1 \mathrm{bB}$ & $1286.4 \mathrm{aA}$ & $1280.2 \mathrm{aAB}$ & $1237.3 \mathrm{aA}$ & $1283.1 \mathrm{aB}$ \\
\hline 200 & $4892.3 \mathrm{aB}$ & $4436.5 \mathrm{aB}$ & $4510.4 \mathrm{aB}$ & $3423.0 \mathrm{bB}$ & $2336.0 \mathrm{aB}$ & $1374.2 \mathrm{bB}$ & $1484.1 \mathrm{aB}$ & $1348.5 \mathrm{bB}$ \\
\hline 400 & $4860.0 \mathrm{aB}$ & $4160.0 \mathrm{aB}$ & $4498.8 \mathrm{aB}$ & $2980.3 \mathrm{bB}$ & $2860.0 \mathrm{aB}$ & $1614.0 \mathrm{bB}$ & $1756.9 \mathrm{aB}$ & $1589.4 \mathrm{bB}$ \\
\hline Average & 4706.0 & 3308.2 & 4303,1 & 2635.1 & 1927.6 & 1301.6 & 1908.5 & 1266.6 \\
\hline $\mathrm{CV}(\%)$ & 18.46 & & 18.67 & & 17.75 & & 19.5 & \\
\hline
\end{tabular}

Note. *Data followed by the same capital letter in the column and small letter on the line in each experiment do not differ significantly by the Tukey test $(\mathrm{P}<0.05)$.

\subsection{Chlorophyll Content}

The contents of chlorophyll $a, b$ and total in soybean leaves from plants of the $\mathrm{Fex}_{1}$, both with and without azoxystrobin + cyproconazole, did not exhibit significant differences between the two groups (Figures 6, 7, and 8). Thus, we chose to present the mean of treatments with and without fungicide. The content of chlorophyll $a$, although not significant, was higher at $400 \mathrm{mg} / \mathrm{dm}^{3}$; for chlorophyll $b$, at $100 \mathrm{mg} / \mathrm{dm}^{3}$; for total chlorophyll, 400 $\mathrm{mg} / \mathrm{dm}^{3}$. The increase of $\mathrm{K}$ fertilizer increased the content of chlorophyll $a$, and the linear model was the best adjusted to the data (Figure 7). For chlorophyll $b$ and total, it was the quadratic model (Figures 7, 8).

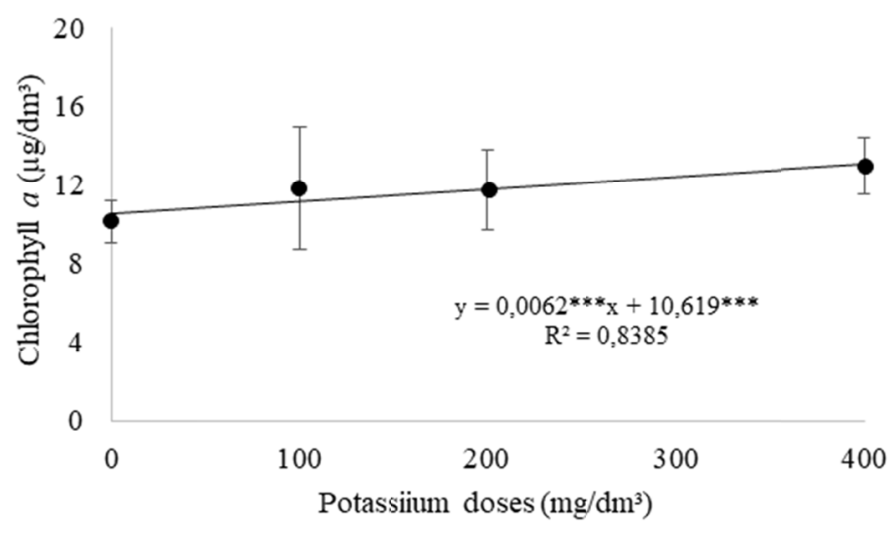

Figure 6. Chlorophyll $a\left(\mu \mathrm{g} / \mathrm{dm}^{3}\right)$ content in soybean plants submitted to different doses of potassium with and without application of azoxystrobin + ciproconazol) in experiment 3 and 4

Note. ${ }^{* * *}$ Significant $0.001 \%$; $* *$ Significant $1 \%$ e *Significant $5 \%$. 


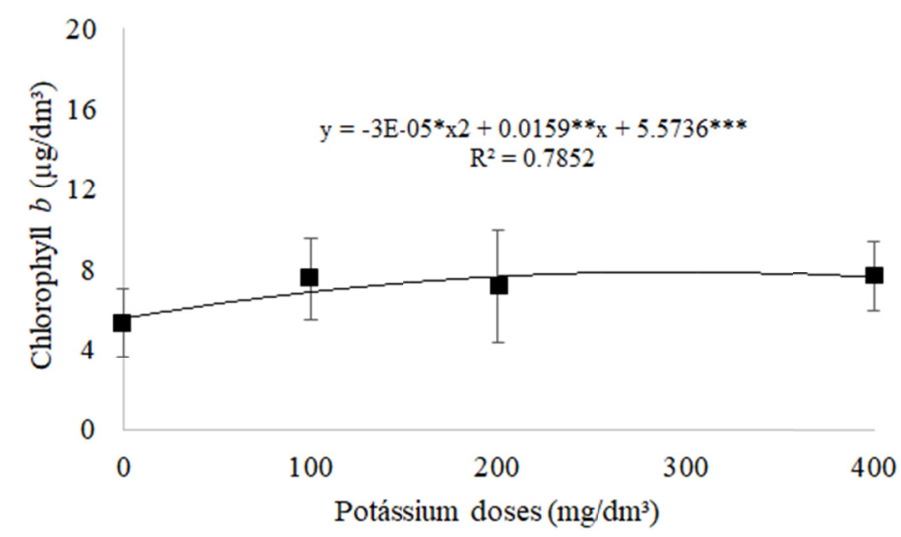

Figure 7. Average chlorophyll $a$ content $\left(\mu \mathrm{g} / \mathrm{cm}^{2}\right)$ in soybean leaves subject to different doses of potassium with and without the application of fungicide (azoxystrobin + cyproconazol) in pot experiments

Note. ${ }^{* * *}$ Significant $0.001 \%$; $*$ Significant $1 \%$ and $*$ Significant $5 \%$.

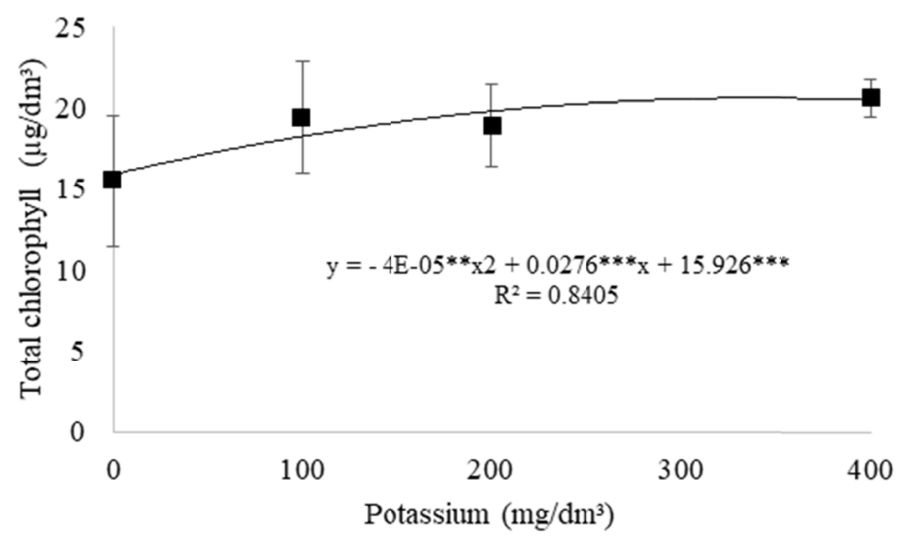

Figure 8. Average total chlorophyll content $\left(\mu \mathrm{g} / \mathrm{dm}^{3}\right)$ in soybean leaves subject to different doses of potassium with and without the application of fungicide (azoxystrobin + cyproconazol) in field experiments

Note. ${ }^{* * *}$ Significant $0.001 \%$; $*$ Significant $1 \%$ and $*$ Significant $5 \%$.

\section{Discussion}

The present work was performed aiming to test the effect of levels of $\mathrm{K}$ and chemical control on the severity of ASR. The high severity of ASR obtained in the experiments was due to the inoculation with uredospores of $P$. pachyrhizi of the border plants in the $\mathrm{Fex}_{1}$ and $\mathrm{Fex}_{2}$ in the field, and directly in the potted plants in $\mathrm{Pex}_{1}$ and $\mathrm{Pex}_{2}$. Overall, in all experiments, the doses of $\mathrm{K}$ fertilizer differed significantly from the control, but the treatments at different doses did not differ from each other. The increase of $\mathrm{K}$ fertilizer reduced the severity and AUDPC of ASR in the plants of all field and pot experiments.

The high susceptibility of the K-deficient plant to disease is due to the metabolic functions of $\mathrm{K}$ in plant physiology. Under K deficiency synthesis of highmolecular-weight compounds (proteins, starch and cellulose) is impaired and there is accumulation of low-molecular-weight organic compounds. Also, $\mathrm{K}$ may promote the development of thicker outer walls in epidermal cells, thus preventing disease attack. K can also influence plant metabolism, as K-deficient plants have impaired protein synthesis and accumulate simple $\mathrm{N}$ compounds such as amides which are used by invading plant pathogens. Tissue hardening and stomatal opening patterns are closely related to infestation intensity (Marschner, 1995).

The best results in the control of ASR at 75 DAE were obtained using $\mathrm{K}$ at $200 \mathrm{mg} / \mathrm{dm}^{3}$, for Fex $\mathrm{Fex}_{2}, \mathrm{Pex}_{1}$, and $\mathrm{Pex}_{2}$. The lowest severity of $\mathrm{Fex}_{1}(20.3)$ and $\mathrm{Fex}_{2}(18.2)$, as well as the lowest values of AUDPC in Fex (910.0), Fex 2 (701.2), $\mathrm{Pex}_{1}$ (676.9), and $\mathrm{Pex}_{2}$ (690.2) were found with the use of $\mathrm{K}$ at $200 \mathrm{mg} / \mathrm{dm}^{3}$. The control rate of ASR, at $200 \mathrm{mg} / \mathrm{dm}^{3}$ of K, varied from $54.8\left(\mathrm{Fex}_{2}\right)$ to $796\left(\mathrm{Pex}_{2}\right)$. For severity, the mean control rate of $\mathrm{Fex}_{1}$ and $\mathrm{Fex}_{2}$, regarding the control, was 66.4 and 57.4, respectively. For AUDPC, it was $68.7\left(\mathrm{Fex}_{1}\right), 80.7$ 
$\left(\mathrm{Fex}_{2}\right), 69.2\left(\mathrm{Pex}_{1}\right)$, and $84.9\left(\mathrm{Pex}_{2}\right)$, respectively. In the regression model, an inflection point was obtained for $\mathrm{K}$ at $200 \mathrm{mg} / \mathrm{dm}^{3}$, corresponding to the lowest severity and AUDPC of ASR.

In $\mathrm{Pex}_{1}$ and $\mathrm{Pex}_{2}$, as the concentration of $\mathrm{K}$ in the soil increased, a linear decrease in severity was obtained. Unlike $\mathrm{Fex}_{1}$ and $\mathrm{Fex}_{2}$, where the amount of $\mathrm{K}$ was high in the field soil, in $\mathrm{Pex}_{1}$ and $\mathrm{Pex}_{2}$, the concentration was $50 \%$ lower. This finding shows that a better response in reducing the severity of ASR with K fertilizer is more likely to be obtained in deficient soils. The excess, deficiency or imbalance in the combinations of different nutritional elements can influence the reaction of the plants to the pathogens, by either increasing or decreasing the plants level of resistance to a disease (Balardin et al., 2006). According to Ito et al. (1994), application of K reduces the incidence of stem and pod drought in soybean, caused by Phomopsis phaseoli var. sojae. However, the authors observed that at very high doses, the frequency of this pathogen was increased, probably due to nutritional imbalance, corroborating with the data found in this study.

The lowest $r$ values in $\mathrm{Fex}_{1}$ and $\mathrm{Fex}_{2}$, with and without fungicide, was 0.74 and 1.53, respectively, at 200 $\mathrm{mg} / \mathrm{dm}^{3}$ of K, whereas in pot experiments was at $400 \mathrm{mg} / \mathrm{dm}^{3}$ of K. Therefore, the lowest $r$ values were obtained at the concentrations of $\mathrm{K}$ two times higher in $\mathrm{Pex}_{1}$ and $\mathrm{Pex}_{2}$ than in $\mathrm{Fex}_{1}$ and $\mathrm{Fex}_{2}$. For the mean values of Fex and Fex ${ }_{2}$ with fungicide, $r$ values decreased from the control to the dose of $400 \mathrm{mg} / \mathrm{dm}^{3}$ around $32.15 \%$; for the mean values of $\mathrm{Pex}_{1}$ and $\mathrm{Pex}_{2}$ without fungicide, $r$ values decreased from the control to the dose of $400 \mathrm{mg} / \mathrm{dm}^{3}$ around $20.95 \%$. Potassium fertilization increases plant resistance to biotrophic or facultative leaf pathogens, as a result of increased tissue stiffness caused by thickening of the cuticle and cell wall, conferring resistance to the penetration and development of the pathogen (Marschiner, 1995). In an experiment aimed at studying different doses of phosphorus and $\mathrm{K}$ and the interaction between them in the control of ASR, Balardin et al. (2006) verified that the increase of $\mathrm{K}$ fertilizer reduced the severity and $r$ of the disease. However, the authors conducted their study in a greenhouse, unlike the present work, in which we performed the experiments in the field. The reduction in the frequency of diseases due to $\mathrm{K}$ fertilizer has also been reported for other pathosystems, such as Peronospora destructor in onion (Develash \& Sugha, 1997), Diaporthe phaseolurum var. sojae and Cercospora kikuchii in soybeans (Mascarenhas et al., 1976; Ito et al., 1993), Sclerotium oryzae and Rhizoctonia oryzae-sativae in rice (Williams \& Smith, 2001).

Soybean plants that received little or no $\mathrm{K}$ fertilizer had higher values of disease severity, AUDPC and $r$. According to Malavolta (2006) deficiency in carbohydrate and amino acid accumulation may occur in $\mathrm{K}$-deficient plants. In this way, there is a lower concentration of proteins (structural, protective and enzymatic), phenols and phytoalexins favoring the onset of diseases. Also, the stomata remain open for a longer time, increasing the chances of penetration of pathogens. According to Balardin (2006), K deficient soybean plants presented higher ASR severity, in a greenhouse.

Regarding the soybean productivity, in the experiments with azoxystrobin + epoxiconazol, the values obtained in the field were above 70 bags ( $60 \mathrm{~kg}$ each) per ha, considered highly suitable for differentiation of the treatments. The highest values obtained in soybean productivity occurred in $\mathrm{Fex}_{1}$ and $\mathrm{Fex}_{2}$ at $200 \mathrm{~m} / \mathrm{dm}^{3}$ and, for $\mathrm{Pex}_{1}$ and $\mathrm{Pex}_{2}$, at $400 \mathrm{mg} / \mathrm{dm}^{3}$. This difference in the concentration of $\mathrm{K}$ between experiment sites may have been due to soil chemical differences. Soils used in pots $\left(\mathrm{Pex}_{1}\right.$ and $\left.\mathrm{Pex}_{2}\right)$ were purposely more deficient in nutrients, while soil in the field experiments $\left(\mathrm{Fex}_{1}\right.$ and $\left.\mathrm{Fex}_{2}\right)$ had considerable amounts of $\mathrm{K}$ and other elements. Also, field experiments were conducted at sites where soybeans had been grown in recent years. Thus, the amount of $\mathrm{K}$ in the soil at the start of the trial was already high, and therefore, the nutrient requirement was lower. Thus, the highest dose $\left(400 \mathrm{mg} / \mathrm{dm}^{3}\right)$ in $\mathrm{Fex}_{1}$ and $\mathrm{Fex}_{2}$ was deleterious to soybean productivity, supposedly due to excess $\mathrm{K}$ in the soil. Therefore, unlike the report by Balardin (2006) and Gonçalves Júnior et al. (2010), the increased concentration of $\mathrm{K}$ in soil did not increase soybean productivity in the present work. Previous soil analysis and the history of the planting area to calculate the number of nutrients in the soil has great importance in increasing or reducing disease severity and in soybean productivity, respectively, besides the possibility of adopting balanced fertilization.

The mean concentrations of $\mathrm{K}\left(0\right.$ to $\left.400 \mathrm{mg} / \mathrm{dm}^{3}\right)$ of fungicide treatments were $29.7 \%\left(\mathrm{Fex}_{1}\right), 38.7 \%\left(\mathrm{Fex}_{2}\right)$, $32.4 \%\left(\mathrm{Pex}_{1}\right)$, and $33.6 \%\left(\mathrm{Pex}_{2}\right)$. The highest rate of increase in soybean productivity was obtained at 200 $\mathrm{mg} / \mathrm{dm}^{3} \mathrm{~K}$ for Fex ${ }_{1}$ and $\mathrm{Fex}_{2}$; for $\mathrm{Pex}_{1}$ and $\mathrm{Pex}_{2}$, the highest rate was at $400 \mathrm{mg} / \mathrm{dm}^{3}$ of $\mathrm{K}$. This difference is due to the fact that the soil of $\mathrm{Pex}_{1}$ and $\mathrm{Pex}_{2}$ was much lower in content of nutrients than the soil of Fex and $\mathrm{Fex}_{2}$. The increased rate of soybean productivity, at $200 \mathrm{mg} / \mathrm{dm}^{3}$ of $\mathrm{K}$ for $\mathrm{Fex}_{1}$ in comparison to the control in the treatment with fungicide was $11.9 \%$ and without fungicide $55.0 \%$; for $\mathrm{Fex}_{2}$ with fungicide $14.5 \%$ and without fungicide $46.8 \%$. At $400 \mathrm{mg} / \mathrm{dm}^{3}$ of $\mathrm{K}$, the increased rate of soybean productivity for Pex $\mathrm{P}_{1}$ in comparison to the control in the treatment with fungicide was $57.0 \%$ without this fungicide, $41.8 \%$; for $\mathrm{Pex}_{2}$, it was $34.2 \%$ with fungicide and $46.8 \%$ without the fungicide. The mean rate of soybean productivity at $100 \mathrm{mg} / \mathrm{dm}^{3}, 200 \mathrm{mg} / \mathrm{dm}^{3}$, 
and $400 \mathrm{mg} / \mathrm{dm}^{3}$, in comparison to the control, for the treatments with fungicides and without fungicides was as follows, respectively: $\mathrm{Fex}_{1}, 11.0 \%$ and $46.7 \%$; $\mathrm{Fex}_{2}, 15.3 \%$ and $50.3 \%$; $\mathrm{Pex}_{1}, 43.1 \%$ and $39.0 \%$; $\mathrm{Pex}_{2} 22.5 \%$ and $39.9 \%$, respectively. We observed that, on average, the effect of $\mathrm{K}$ on the increase of soybean productivity was higher in treatments without fungicide $(43.9 \%)$ than in treatments with this chemical $(22.9 \%)$. Excessive doses of K can reduce soybean productivity and dry mass (Reis Júnior (1995), as well as reduce the absorption of calcium and magnesium (Fageria, 2001). In this study in plants that did not receive $\mathrm{K}$ fertilizer, soybean productivity was lower in comparison to the plants that received. According to Sacramento and Rosolem (1998), $\mathrm{K}$ is an essential macronutrient in soybean mineral nutrition and one of the nutrients that is absorbed and exported in the highest amounts. Thus, K-deficient plants produce small, deformed, wrinkled grains and thus delay the maturity of soybeans, with crops remaining longer in the field exposed to pests and diseases (Borkert et al., 1994).

ASR has a high destructive potential to the soybean crop. In this study the application of fungicide was essential to slow the progress of the disease and ensure high productivity.

Barbosa et al. (2014) indicated that applying azoxystrobin + cyproconazol in soybean provided better control of this disease, positively contributing to soybean grain yield.

The increase of the $\mathrm{K}$ fertilizer increased the contents of chlorophyll $a$ and $b$. Potassium appears to be associated with the formation of a chlorophyll precursor or may act to prevent its degradation (Datnoff, 2007). The increase in the content of chlorophyll due to the rise in K fertilizer was reported by Rodrigues et al. (2014) in corn and by Souza et al. (2016) in radish. The contents of chlorophyll $b$ in plants that received chemical control were higher in comparison to the plants that were not treated with fungicide. The increase in the content of chlorophyll $b$ is essential as this pigment captures energy from other wavelengths and then transfers it to chlorophyll $a$, which effectively acts on the photochemical reactions of photosynthesis (Taiz \& Zeiger, 2013). The fungicide used in these experiments had a strobilurin (azoxystrobin) as a base, which has the characteristic of promoting the increase of the content of chlorophyll due to the rise in the assimilation of nitrogen, and reduction of the ethylene productivity, resulting in the "green effect". These factors contribute to lower plant stress, resulting in higher soybean productivity (Tofoli et al., 2002). Besides, the molecules of this group act to prevent spore germination and have eradicating and corrective action, inhibiting the development of pathogens in the early stages after spore germination (Venâncio et al., 1999). Our study showed that in the presence or absence of K by keeping the soybean leaves healthy with fungicides (triazol + strobilurin), the chlorophyll content tend to increase leading to an increase in soybean yield.

\section{Conclusion}

The hypotheses that potassium fertilization reduces the severity of Asian soybean rust, under high disease pressure with or without chemical control was accepted. The best results were obtained when potassium was added in the soil and chemical control with azoxystrobin + cyproconazol. Increasing potassium doses disfavored Asian soybean rust control and grain yield.

\section{References}

Andrade, P. J. M., \& Andrade, D. F de A. A. (2002). Ferrugem asiática: Uma ameaça à sojicultora brasileira. Embrapa Agropecuária Oeste-Circular Técnica (INFOTECA-E).

Balardin, R. S., Dallagnol, L. J., Didone, H. T., \& Navarini, L. (2006). Influência do Fósforo e do Potássio na Severidade da Ferrugem da Soja Phakopsora pachyrhizi. Fitopatologia Brasileira, 31(5), 462-467. https://doi.org/ $10.1590 / \mathrm{S} 0100-41582006000500005$

Barbosa, G. F. (2014). Potencial do manejo integrado da ferrugem asiática da soja: Severidade da doença, desenvolvimento vegetativo e componentes da produção, cultivar MG. Bioscience Journal, 30(3).

Basseto, M. A., Ceresini, P. C., \& Valerio Filho, W. V. (2007). Severidade da mela da soja causada por Rhizoctonia solani AG-1 IA em função de doses de potássio. Summa Phytopathologica, 33, 56-62. https://doi.org/10.1590/S0100-54052007000100008

Bhaskarachary, K. 2011. Potassium and human nutrition: The soil-plant-human continuum. Karnataka Journal of Agricultural Sciences, 24, 39-44.

Borkkert, C. M., \& Da Costa, N. P. (1988). Potassium fertilization reduces disease and insect damage in soybeans. Crop quality and plant health. Potash Review/Intern. Potash Inst.

Chase, A. R. (1989). Effect of nitrogen and potassium fertilizer rates on severity of xanthomonas blight of Syngonium podophyllum. Plant Disease, 73, 972-975. https://doi.org/10.1094/PD-73-0972 
CONAB (Companhia Nacional de Abastecimeto). (2017). Boletin de safra de grãos, 2007/2018.

Datnoff, L. E., Rodrigues, F. A., \& Seebold, K. W. (2007). Silicon and plant disease. In L. E. Datnoff, W. H. Elmer, \& D. M. Huber (Eds.), Mineral nutrition and plant disease (pp. 233-246). St. Paul: The American Phytopathological Society Press.

Deshmukh, S. S., Mayee, C. D., \& Kulkarni, B. S. (1978). Reduction of downy mildew of pearl millet with fertilizer management. Phytopathology, 68, 1350-1353. https://doi.org/10.1094/Phyto-68-1350

Develash, R. K., \& Sugha, S. K. (1997). Factors affecting development of downy mildew (Peronospora destructor) of onion (Allium cepa). Indian Journal of Agricultural Sciences, 67, 71-74. https://doi.org/ 10.1016/S0261-2194(96)00056-7

Fageria, V. D. (2001). Nutrient interactions in crop plants. Journal of Plant Nutrition, 24, 1269-1290. https://doi.org/10.1081/PLN-100106981

Fernandes, M. S. (2006). Nutrição mineral de plantas. Sociedade Brasileira de Ciência do Solo. Viçosa, Minas Gerais.

Gonçalves Junior, A. C. (2010). Produtividade e componentes de produção da soja adubada com diferentes doses de fósforo, potássio e zinco. Ciênc. Agrotec., 34, 660-666. https://doi.org/10.1590/S1413-7054201000 0300019

Huber, D. M., \& Arny, D. C. (1985). Interactions of potassium with plant disease. In R. D. Munson (Ed.), Potassium in Agriculture (pp. 467-479). America Society of Agronomy. Madison.

Ito, M. F., Tanaka, M. A. S., Mascarenhas, H. A. A., Tanaka, A, R. T., Dudienas, C., \& Gallo, P. B. (1993). Efeito residual da calagem e da adubação potássica sobre a queima foliar (Cercospora kikuchii) da soja. Summa Phytopathologica, 19, 21-23.

Kranz, J. (1988). Measuring plant disease. In J. Kranz, \& J. Rottem (Eds.), Experimental techniques in plant disease epidemiology (pp. 35-50). Heidelberg: Springer-Verlag. https://doi.org/10.1007/978-3-64295534-1_4

Malavolta, E. (2006). Manual de nutrição mineral de plantas. São Paulo: Agronômica Ceres.

Marschner, H. (1996). Relations hip between mineral nutrition and plant disease and pests. In H. Marschner (Ed.), Mineral nutrition of higher plants (pp. 369-390). London, Academic Press. https://doi.org/10.1016/ B978-012473542-2/50013-4

Mascarenhas, H. A. A. (1995). Ocorrência de fungos em sementes de soja produzidas sob calagem e adubação potássica residuais. Sci. Agric., 52, 426-430. https://doi.org/10.1590/S0103-90161995000300004

Mascarenhas, H. A. A., Miranda, M. A. C., Bataglia, O. C., Tisseli Filho, O., Braga, N. R., \& Soave, J. (1976). Efeito da adubação potássica sobre o ataque da soja pelo Diaporthe phaseolorum (Cke. \& Ell.) Sacc.var. sojae (Lehman) Wehm. Summa Phytopathologica, 2, 230-234.

Oliveira, A. F. (2007). Produtividade da soja e severidade de ferrugem asiática (Phakopsora pachyrhizi) influenciadas pela aplicação foliar com fontes de potássio e doses de Tebuconazole (Dissertação Mestrado, Universidade Federal de Uberlândia, Uberlândia).

Pacumbaba, R. P., Brown, G. F., \& Pacumbaba Jr., R. O. (1997). Effect of fertilizers and rates of application on incidence of soybean diseases in Northern Alabama. Plant Disease, 81, 1459-1460. https://doi.org/10.1094/ PDIS.1997.81.12.1459

Perrenoud, S. (1990). Potassium and Plant Health (2nd ed.). IPI Research Topic No. 3. International Potash Institute, Horgen, Switzerland.

Reis Junior, R. dos A. (1995). Produção, qualidade de tubérculos e teores de potássio no solo e no pecíolo de batateira em resposta à adubação potássica (Dissertação Mestrado, Universidade Federal de Viçosa, Viçosa. $\mathrm{MG})$.

Rodrigues, M. A. de C. (2014). Adubação com KCl revestido na cultura do milho no Cerrado. Revista Brasileira de Engenharia Agrícola e Ambiental, 127-133. https://doi.org/10.1590/S1415-43662014000200001

Sacramento, L. V. S., \& Roselem, C. A. (1998). Eficiência de absorção e utilização de potássio por plantas de soja em solução nutritiva. Bragantia, 57, 355-365. https://doi.org/10.1590/S0006-87051998000200017 
Sij, J. W., Turner, F. T., \& Whitney, N. G. (1985). Supression of antracnose and phomopsis seed rot on soybean with potassium fertilizer and benomyl. Agronomy Journal, 77, 639-642. https://doi.org/10.2134/ agronj1985.00021962007700040029x

Souza, G. P., Lima, L. G. F., Borges, I. A., Benett, C. G. S., \& Benett, K. S. S. (2015). Manejo da adubação potássica para a cultura do rabanete. Revista de Agricultura Neotropical, 2, 60-64. https://doi.org/10.32404/ 2358-6303-rean.v2i4.287-2015

Taiz, L., \& Zeiger, E. (2013). Fisiologia Vegetal (3rd ed., p. 954). Porto Alegre: Artmed Editora.

Tofoli, J. G., Oliveira, S. H. F., Domingos, R. J., Santos J. M. F., \& Martins, E. M. F. (2002). Desempenho de azoxystrobin no controle da ferrugem do cafeeiro sob condições de chuva induzida. Arquivos do Instituto Biológico, 69, 93-96.

Vale, F. X. R. (2003). A software plant disease severity assessment (p. 105). International Congress of Plant Pathology, 8, 2003, Christchurch. Proceedings... Christchurch: Plant Pathology Society.

Venâncio, W. S. (1999). Novos fungicidas. I-Produtos naturais e derivados sintéticos: Estrobilurinas e fenilpirroles. Revisão Anual de Patologia de Plantas, 7, 103-155.

Williams, J., \& Smith, S. G. (2001). Correcting potassium deficiency can reduce rice stem diseases. Better Crops, $85,7-9$.

Yorinori, J. T., Nunes Júnior, J., \& Lazzarotto, J. J. (2004). Ferrugem "asiática" da soja no Brasil: Evolução, importância econômica e controle. Embrapa Soja-Folderes/Folhetos/Cartilhas (INFOTECA-E).

Zambolim, L. (2006). Ferrugem Asiática da Soja (1st ed., p. 140). Viçosa, Minas Gerais.

Zambolim, L., Ventura, J. A., \& Zanão J., L. A. (2012). Influência da nutrição mineral no controle de doenças de plantas (p. 321). Viçosa, Minas Gerai.

\section{Copyrights}

Copyright for this article is retained by the author(s), with first publication rights granted to the journal.

This is an open-access article distributed under the terms and conditions of the Creative Commons Attribution license (http://creativecommons.org/licenses/by/4.0/). 